\title{
Chapter 2 \\ Constructing the Australian School History \\ Curriculum: Ideology, High Politics and the \\ History Wars in the Howard Years
}

\author{
Tony Taylor
}

This chapter is a substantially revised and expanded version of a keynote address "Disputed Territory: Who Owns History in Schools?" given at the Australian National University Research School of Social Sciences' conference "Governing by looking back" 12-14 December (2007).

The relevant official government papers for the summit, including an edited transcript of proceedings, have been archived on the Department of Employment Education and Workplace Relations website at http://www.dest.gov.au/sectors/school_education/ policy_initiatives_reviews/key_issues/Australian_History/ (as at July 2009)

\subsection{Background to Policy and History Curriculum}

In 1996, a Liberal/National conservative coalition was victorious in the Australian March general election and coalition leader, John Howard, became the nation's 25th prime minister. Howard's accession, bolstered by a large majority, came following his own long and difficult political apprenticeship and after 13 years of Labour federal government. Although focused throughout his next three administrations on the big political issue including race relations, immigration policy, Middle East conflict, privatisation and industrial relations, Howard still kept time for history, which, after small beginnings, began to loom increasingly large in the prime minister's consciousness. This incipient public attention to history began in 1996 in his Sir Thomas Playford memorial speech where he accused "cultural dieticians in our midst" of attempting to "rewrite Australian history in the service of a partisan political cause."1 His comments were aimed at academics and others who favoured what had already been referred to by conservatively inclined historian Geoffrey Blainey as the "black armband" view of Australia's past. In other words, a view that was sympathetic to Aboriginal travails and hostile to some aspects of European

T. Taylor $(\bowtie)$

Monash University, Faculty of Education, Gippsland Campus,

Northways Road, Churchill, Victoria 3842, Australia

${ }^{1}$ John Howard, Sir Thomas Playford Memorial Lecture, Adelaide Town Hall, 5 July 1996. 
settlement in the continent. In October 1996 Howard spoke in parliament of the "black armband" view, arguing that "the balance sheet of Australian history is overwhelmingly a positive one." 2

History lay in abeyance in the prime minister's mind as other matters took precedence, until 1999 when two distinguished professional historians Stuart Macintyre and John Hirst (the former leftish by inclination, and the latter rightish) made representations about the poor state of history in Australian schools. The federal government, following the advice of Education Minister David Kemp, established a national inquiry (1999-2000) which clearly showed that, in a majority of states and territories, history was an all but invisible subject, inadequately subsumed within a generic and controversial approach to social education known as Studies of Society and Environment (SOSE). ${ }^{3}$ The exception was New South Wales, the prime minister's home state, where history was not only firmly on the timetable but compulsory in years 9 and 10, where Australian history was allocated a minimum of $100 \mathrm{~h}$ class time. It was not an insignificant factor in what followed that Bob Carr, premier of New South Wales and a traditionalist Labour politician was to be recruited by Prime Minister Howard to support conservative concerns about history in schools. Carr, a former journalist and a history autodidact, had a serious, almost professional, interest in the discipline which he had forcefully carried into his state's education system.

Over the next 5 years, political interest in Australian history built up a head of steam in what were to become known generally as the "culture wars" and more specifically as the "history wars." The conflict lay between on the one hand, a Blainey-inspired conservative faction led by polemicist Keith Windschuttle, buoyed by Rupert Murdoch's The Australian newspaper and, to some extent, urged on by Howard. The other, less politically skilled and less united faction comprised mainly bemused historians and excitable pundits who were largely overwhelmed by the vehemence and by the media clout of the other side. It was then that a serious political crisis intervened and raised the historical stakes. ${ }^{4}$

\subsection{Ideology and School History}

The Australian history wars in the first years of the new century followed on from, and were similar in character to, conflicts that had divided scholarly opinion, educators and politicians in the UK and in the USA in the previous decade. In the UK, following Prime Minister Margaret Thatcher's 1988 introduction of a national

\footnotetext{
${ }^{2}$ Both speeches are commented on in Macintyre and Clark (2003) pp. 136-139 and Taylor (2004) pp. 220-221.

${ }^{3}$ Taylor (2000) The Future of the Past

${ }^{4}$ The best summary of the culture wars can be found in Macintyre and Clark (2003). Taylor (2008) has a useful chapter on the Windschuttle debate pp. 174-209.
} 
curriculum (under the auspices of education minister Kenneth Baker) and bearing in mind Thatcher's special interest in British (really English) history, an ideologically based conflict broke out on the grounds, simply put, that there was not enough national content in the proposed history programme, it was too left wing in orientation and contained far too few facts. It was the conservative Daily Telegraph that led the UK media charge, a conservative professional historian and political scientist Robert Skidelsky who led the public opinion charge and a previously obscure conservative history teacher who led a (small-scale) professional charge. This campaign against perceived leftist influence led to direct intervention by the prime minister and her ministers with first versions of the programme modified to suit a Thatcherite worldview. ${ }^{5}$

In the USA, following on from the Bradley Commission's 1989 publication Historical Literacy: The Case for History in American Education and the establishment of national standards in 1994, a furious public debate centred on the contentious, allegedly left-leaning components in the standards was led by a strong, neo-conservative faction that included the Wall Street Journal (not, at that time, a Murdoch outlet), public figures such as shock jock Rush Limbaugh and high-profile polemicist Lynne Cheney, as well as politicians including Bob Dole and Newt Gingrich. The more heated phase of the national debate continued over a 2-year period (1994-1996), with the national standards eventually republished in 1996 as a far less controversial voluntary programme for US schools. ${ }^{6}$

In brief, the ideological basis for these history wars was threefold. First, a neoconservative view that education systems and cultural outlets were dominated by left-wing politics and the 1990s was a decade in which neo-conservatives needed to strike back and strike hard. The second motivation for action was a trenchant neo-conservative and assimilationist form of nationalism, that was resistant to multi-culturalism and to any form of exceptional treatment for new minorities and to narrative "relativism"; hence, the emphasis on a single national story at the expense of multiple stories and multiple perspectives. A third factor in the campaign against a progressive view of history education was the narrowly didactic notion that students should learn the "facts" of history at the expense of dealing with historical events as a basis for discussion and well-founded explanation.

\subsection{The Australian Initiative for National Curriculum}

In late 2005, agitated by ethnic clashes in the Sydney beachside suburb of Cronulla, Howard announced that, as part of his government's drive to bring the different ethnic groups in Australian society together, there would be a "root and branch" renewal of history education. A point had now been reached where Howard was

\footnotetext{
${ }^{5}$ The best analysis of the Thatcher approach can be found in Phillips (1998).

${ }^{6}$ See Nash et al. (1999) for the US school history wars.
} 
looking to leave a legacy in Australian history, particularly in how it was studied in schools, and the "renewal" would help solve a national problem. ${ }^{7}$

This narrative is therefore a memoir of events that occurred during the period 2006-2007 when John Howard, attempting to emulate Bob Carr, struggled to introduce compulsory Australian history into the school curriculum across all states and territories, at a time when there was no national curriculum. This was to be his abiding contribution to the "culture wars between left and right. The dramatis personae includes Howard himself (as a neo-liberal with an interventionist and special interest in Australian history), federal minister of education Julie Bishop (a more centrist and a more pragmatic conservative), a little-known political staffer John Kunkel, Geoffrey Blainey, a well known historian and Chris Mitchell, editor of The Australian newspaper and confrontational culture warrior-in-chief."

\subsubsection{A Narrative Memoir}

During the period 1999-2009, the author has been closely involved in history education policy at the federal level as director of the national history inquiry 1999-2000, director of the national history centre 2001-2007, lead presenter at the national history summit 2006, lead consultant in the Howard government's attempt to introduce a national curriculum (sic) in Australian history and as co-consultant in the history element of the Rudd government's national curriculum initiative 2008-2009. However, as with all memoirs, the narrative represents the author's views. The suggested significance of the narrative however lies in its attempt to portray the inner workings of a conservative government in full, ideological cry and the fraught relationship between partisan political activity, on the one hand, and professional aims and goals of history educators on the other hand.

And, when it comes to history education there are huge numbers involved. We are dealing with the minds and hearts of approximately 3.5 million school students in Australia, attending over 9,000 schools and taught by almost a quarter of a million teachers. All primary school students study historical themes, generally in an integrated curriculum, and a massive number of secondary schools students are supposed to study history, again, in a variety of formats.

The line taken during the period prior to the Howard government's third-term history initiatives by the history professionals, through both the History Teachers' Association of Australia (HTAA) and the Australian Historical Association (AHA), has been that political interference from either side of politics is unwelcome and can be resisted by following a clear approach to historical literacy, as developed by the National Centre for History Education (www.hyperhistory.org). The literacies were endorsed by the HTAA and the AHA in 2005 as a prominent part of a professional

\footnotetext{
${ }^{7}$ See, for example, The Age 25th January 2006 'PM lays out vision for Australia'.
} 
set of standards; at the time there was optimism amongst some members of the professional history community that we were making progress away from the tangled web of political conflict.

The idea behind the standards was to set a professional basis for discussion in the face of an anticipated neo-liberal push for curricular reform in which I, at least, anticipated the imposition of a simplistic policy view that if school history was made compulsory, it would automatically improve student knowledge. ${ }^{8}$ That was until John Howard dropped post-Cronulla, Australia Day 2006 bombshell. In what was a strongly assimilationist speech to the Australian National Press Club in the Great Hall of Parliament, Howard proposed a major reform in history teaching in schools. This, in part, is what he said:

\begin{abstract}
I believe the time has also come for root and branch renewal of the teaching of Australian history in our schools, both in terms of the numbers learning and the way it is taught. For many years, it's been the case that fewer than one-in-four senior secondary students in Australia take a history subject. And only a fraction of this study relates to Australian history. Real concerns also surround the teaching of Australian history in lower secondary and primary schools. Too often history has fallen victim in an ever more crowded curriculum to subjects deemed more "relevant" to today. Too often, it is taught without any sense of structured narrative, replaced by a fragmented stew of "themes" and "issues." And too often, history, along with other subjects in the humanities, has succumbed to a postmodern culture of relativism where any objective record of achievement is questioned or repudiated. ${ }^{9}$
\end{abstract}

History was now up for Howard's neo-liberal "root and branch" renewal.

\title{
2.4 The History Summit: August 2006
}

After his top-down (by implication) and assimilationist Australia Day speech, there followed a 5-month hiatus, probably because Howard and his staff and cabinet were distracted by other, more pressing, issues and were trying to work out how to make the "root and branch" strategy happen.

On 4 July 2006, Julie Bishop opened the next round in top-down negotiations by announcing a history summit, scheduled for an unspecified time later in the year, and especially set up to found a narrative-based, stand-alone approach to Australian history in primary and secondary schools (from years 3-10). Bishop's language was moderate, promising a collaborative approach, but her office had clearly leaked

\footnotetext{
${ }^{8}$ The curriculum approach that I was working from was a four stage model: (1) intended curriculum, or the political/administrative agenda hidden and/or public; (2) stated curriculum, or what the curriculum documentation says should happen; (3) enacted curriculum, or what actually happens in the classroom and (4) realised curriculum, or what students will know and understand. Neoliberal attitudes favoured knowledge (facts) over understanding.

${ }^{9} \mathrm{~A}$ full transcript is downloaded from http://www.australianpolitics.com/news/2006/01/06-0125_howard.shtml July 2009.
} 
to The Australian that a big stick would be used if the states and territories refused to come across. ${ }^{10}$ Meanwhile, Howard said his role would be hands-off, describing himself as an "amateur historian." This became a characteristic feature of the rhetoric at that time and later. Howard and Bishop promised collaboration, historical balance and multiple narratives, as long as the states and territories did as they were told, and agreed to Howard's vision of Australian history, whatever that might be.

Prior to the convening of what was to become the August 2006 summit, the Howard government commissioned me to review the teaching and learning of Australian history in schools around the nation. Monash colleague Dr Anna Clark and I divided up the national audit and it was then my job to compile and write the report, which was very critical of most state and territory history provision, especially those jurisdictions that adopted the generic approach to social education known as SOSE. ${ }^{11}$ At that time I was told by an official that another report was being prepared by an academic historian, Greg Melleuish, from the University of Wollongong, and his report was to form the basis of a "national syllabus."12

It is important to point out that at that stage a very senior official from what was then Department of Education, Science and Training (DEST) told me on the phone that my job was to keep the summit participants' (later known as the "Summiteers") feet on the ground. The same official also pointed out to me that the prime minister's office was concerned about my role because they considered me to be "politically unreliable." The impression I got was that senior DEST officials, who have to deal with the states and territories on a daily basis, were trying to keep the process sensible, sane and professional, while dealing with political demands from outside DEST, more from the prime minister's office but also from the education minister's office.

The Melleuish appointment came as a complete surprise to many historians and to all the history teachers I knew. Why was Melleuish selected instead of, for example, the much better known John Hirst, who had just spent a decade working closely with DEST on school resources? Hirst, a highly regarded and prolific specialist in Australian history, would arguably have been the first choice of many historians and teachers. By contrast, New South Wales-based Melleuish was a relatively unknown academic historian with no background in history education.

\footnotetext{
${ }^{10}$ See for example Imre Salusinszky's article 'History back in schools' The Australian, 5th July 2006 in which he comments, 'If they (the states and territories) refuse (to accept the history curriculum) The Australian understands the government will consider making the teaching of Australian history a condition of its next schools funding agreement with the states'. See also another Murdoch outlet The Sunday Telegraph, August 20th 2006 'Conform or you're history' in which political commentator Glenn Milne wrote that the states would 'lose' \$33 billion of federal funding (sic) unless they adopted a new history curriculum. At about that time, and thereafter until 2007, there was strong speculation amongst informed observers (mainly non-Murdoch journalists) that The Australian had a pipeline to the PM's and to Julie Bishop's offices

${ }^{11}$ Taylor \& Clark (2006)

${ }^{12}$ Melleuish (2006)
} 
So obscure was he that even my New South Wales teaching contacts asked me if I knew anything about him. I did not, apart from a vague, residual memory that somebody from Wollongong University had once attacked Melbourne University historian Stuart Macintyre over Australian Research Council grants, but I was not sure it was Melleuish.

It would be an understatement therefore to say that the history teachers that I knew across Australia were baffled by Melleuish's selection. Nevertheless, perhaps they were reassured by the Howard government's announcement that the summit would be peopled by historians, and others, from the "sensible centre." ${ }^{13}$ Crucially, in the pre-summit speech, Bishop revealed the Howard agenda when she commented: "History is not peace studies. History is not social justice awareness week. Or conscious-raising about ecological sustainability. History is history, and shouldn't be a political science course by another name. This is a belief I know Bob Carr shares and his role in reinstating Australian history as a key subject in NSW provides a model for what I believe needs to happen on a national scale."14

As it happened, any close analysis of the Summiteers, even allowing for the presence of such distinguished non-conservatives as Geoffrey Bolton and Ingae Clendinnen, would show that the group leaned well to the right. There was also a concentration of New South Walers, including a columnist representative from The Australian, Paul Kelly and conservative Fairfax Press writer, Gerard Henderson. On the other hand, non-invitees included right-wing controversialists Keith Windschuttle and Andrew Bolt (controversial shock columnist in Melbourne's Herald Sun), as well as leftish historians Henry Reynolds and Lyndall Ryan. Other absentees included Stuart Macintyre (invited, but unable to attend). Crucially, representatives from the states and territories were not invited.

In setting up the summit in this way, Howard had sidestepped the states who were now were out of the loop, much to their fury. Clearly, Howard and Bishop thought they had both the moral weight (who could argue with recommendations from the "sensible centre"?) and the political clout (control of both federal houses of parliament and an $\$ 8$ billion per annum Canberra-based schools budget) to carry out their intentions.

However, despite characterisations of the summit as a meeting of the "sensible centre," what I subsequently discovered was that invitee Greg Melleuish had strong ties to neo-conservative magazines New Criterion (USA) and Quadrant (Australia)

\footnotetext{
${ }^{13}$ Julie Bishop's pre-summit dinner speech, see ministerial press release 16th August 2006 'Forgetting our Past, Failing our Future: the Teaching of Australian History'. Bishop also made the following highly significant comment,' History is not peace studies. History is not social justice awareness week. Or conscious-raising about ecological sustainability. History is history, and shouldn't be a political science course by another name. This is a belief I know Bob Carr shares and his role in reinstating Australian history as a key subject in NSW provides a model for what I believe needs to happen on a national scale.'

${ }^{14}$ Speech at pre-summit dinner, 16th August 2006, downloaded from http://www.htansw.asn.au/ home/nationalcurriculum/Bishop\%20Summit\%20Dinner\%20Speech $\% 2016 \% 20$ August $\% 20$ 2006.pdf July 2009.
} 
and to the right-wing centre for Independent Studies (CIS). He had also, with Australian columnist Imre Salusinszky, co-edited a conservatively inclined volume, Blaming Ourselves: September 11th and the Agony of the Left, published by Keith Windschuttle's polemical cottage industry, Macleay Press. Furthermore, Melleuish had indeed publicly attacked Stuart Macintyre, in several fairly disagreeable ways, in a 2003 review of the book History Wars, ${ }^{15}$ at the same time taking a personal swipe at Macintyre's co-author Anna Clark, accurately but egregiously accusing her of being the granddaughter of a major Australian historian, the "unpleasant" (Melleuish's word) Manning Clark, and inaccurately alleging that she had attempted to conceal the fact. This tirade was to be followed by what can only be described as a querulous anti-Macintyre rant in the CIS journal Policy. Here is a taste of it:

\begin{abstract}
About Stuart Macintyre's attitude to Melleuish: "He refuses to name me or to acknowledge that I am a professionally trained historian..." About unnamed historians: "Their preference is to do their dirty work in secret by ensuring that research with which they disagree does not receive funding..." and "Macintyre as the self-appointed shop steward of the history profession is trying to... argue the case for a closed shop in historical debate..." And, in what might be considered an interesting piece of neo-liberal projection: "The willingness of people like Macintyre to subordinate the quest for historical truth to contemporary politics."
\end{abstract}

If we search for motivation for the rant, we can turn to a professional disagreement Melleuish apparently had with Macintyre in 1989 over what constituted good and bad history. The two had already differed substantially over a 1988 Melbourne University entanglement when Geoffrey Blainey was seen as a victim of leftist conspirators, one of whom, it was recklessly alleged by Blainey supporters, was the ex-Marxist Macintyre. This anti-Macintyre disposition remains a constant part of the Chris Mitchell/The Australian myths-and-fables approach to the history wars.

So why was Greg Melleuish selected? We can only speculate why someone with no connection to history education was asked to take on such an important task. Remember, this is the first serious attempt by any Australian federal government to push through a detailed "national curriculum." My guess is that there was little choice for Howard. Who else would appeal to neo-conservatives and yet avoid being seen as an outrageously partisan choice? Windschuttle and Blainey would have failed that test. Hirst, who was his own man politically, may have been considered too close to teachers by Howard's office. Macintyre was clearly out of contention. Melleuish was almost certainly chosen because he had clearly and publicly shown his political leanings and because his relative anonymity meant he was a small target for the media. In that way, he could be represented as the dutiful scholar rather than as a political advocate.

Perhaps the prime minister was also influenced by Melleuish's piece in The Australian on 30 January 2006, after Howard's Australia Day speech. "A better way of looking at the past" was a Howardite encomium, including yet another ad hominem

\footnotetext{
${ }^{15}$ Policy, Summer 2003-04 downloaded from http://www.cis.org.au/Policy/summer03-04/ polsumm0304-7.htm July 2009.
} 
attack on Stuart Macintyre and which extolled the importance and virtue of the Enlightenment and (Judaeo) Christian ethics (which also happen to be two of Windschuttle's many obsessions). ${ }^{16}$

It seems, therefore, that the History Summit process was nothing less than an indefatigable and individual "Quadranteer" being given free rein to construct a national programme of study in Australian history, backed by the prime minister and by the prime minister's newspaper of choice, The Australian, led by crusader Chris Mitchell. That was the underlying Howard agenda, inadequately concealed by the term "sensible centre."

\subsection{Responses to the Australian National History Curriculum Summit}

At first, there was the cautiously polite and positive view that at last Australian history was being taken seriously. The summit, it was argued, would inevitably benefit the discipline by placing Australian history front and centre in the curriculum. More pessimistic observers however regarded the summit as a fix. Cutting the states and territories out of the deal, bringing in former New South Wales (NSW) state premier Bob Carr as a token Labourite (whose views happened to be close to Howard's on school history) and asking Melleuish to provide a sample syllabus were developments seen by some as an attempt to impose a right-wing NSW solution on the whole of Australia. My NSW teacher contacts thought so. As far as they were concerned, with Carr there, the initiative was a blatant attempt by Howard, a Carr fan, to copy the state premier's 1998 introduction of compulsory Australian history into NSW secondary schools in years 9 and $10 .{ }^{17}$

We then waited with bated breath to see what Melleuish would come up with. Gloomier colleagues were not disappointed. Melleuish's draft structured narrative for years 9 and 10 gave due prominence to the Enlightenment, just as the prime minister had, in his January speech, suggested it should. It also dealt with Indigenous history, as Howard also suggested it should. Oddly, but not unexpectedly,

\footnotetext{
${ }^{16}$ From early 2006 to mid-2007 Melleuish published nine articles in The Australian, mainly on history education topics, clearly not his area of expertise.

${ }^{17}$ See, for example, 'Courses should be designed by teachers not by politicians' (letters), The Australian, 6th July 2006; History's Forgotten Voices (Anna Clark, opinion editorial), The Age 15th July 2006; 'The Return of History' (editorial), The Age 6th August 2006; 'History on a Pedestal' (Imre Salusinszky, feature), The Weekend Australian 12-13th August 2006; 'The whole world must be the story' (Richard Allsop, opinion editorial), The Australian 15th August 2006; 'Howard is trying to leave history students stranded in the past' (Les Terry, opinion editorial), The Age 17th August 2006. On August 18th, The Australian had still failed to pick up the errant direction in which the summit had gone the previous day, see, 'Summit calls for history classes to go back to tradition, The Australian 18th August 2006.
} 
considering the political context, the topic on the Enlightenment came before the first substantive topic on indigenous Australia. The primary section got a few stabs at what little children might do. ${ }^{18}$

All in all there were 49 major topics in secondary, most of them dry and abstract in nature. I calculated that it would take well over $300 \mathrm{~h}$ to teach this course even if you wanted to. Indeed, some of the topics could occupy a whole term's work. True, the programme was not manifestly ideological. My (later) polite public take on it was that it was a "worthy effort" by someone who, as a non-teacher, had been given a tough job and just did not know what he was doing. In purely professional terms, it was as if a little-known schoolteacher had been asked by the Australian Research Council to draft its next 5-year plan. And it was this process, disassociated as it was from conventional professional practice that flagged what the government was up to. Howard did not trust the (radical) teachers and curriculum designers to do their job and had called in Melleuish, a politically sympathetic specialist from an allied but very, very different field to take on the task.

Furthermore, as far as the summit agenda was concerned, my view and the view of my colleagues was that, on the day, my job was to provide the anti-SOSE entrée and Melleuish was to be the main course. Knowing that was almost certainly the case, and having been allocated a 10-min address in the opening stages, I decided it was important to try to re-set the day's agenda. After consultation with a trusted NSW friend and ally, the solution was to forestall any summit rubber-stamping by drafting an introduction which insisted that whatever came out of the day, it had to be teachable, doable and sustainable. In other words, the curriculum must engage students and teachers; it must be structured in a way that the topics could be covered properly and it must be acceptable to the states and territories who would have the task of supporting it. Clearly, Melleuish's proposed syllabus was going to be none of these things. It was dry and abstract in nature, it was over-stuffed with difficult, time-consuming topics and the summit process has already alienated the states and territories.

\subsection{The Australian National History Curriculum Summit}

The seating arrangement of the summit was interesting. Held in one of the large committee rooms, the Summiteers were arranged in alphabetical order around a rectangle of tables. Geoffrey Bolton and Geoffrey Blainey, being "B"s were sat to the left of the chair and I, being a " $\mathrm{T}$ " was sat to the right of the chair, and it was from this interesting micro-political position that I launched my teachable, doable, sustainable attempt to set the agenda. Following my opening remarks, a rambling

\footnotetext{
${ }^{18}$ In what was a portent of what was yet to come, the summit organisers had forgotten to nominate a primary school representative. After some hasty checking of DEST contact lists, one was invited at the very last minute.
} 
morning's discussion ensued but the general consensus was that teachable, doable and sustainable would constitute the criteria for creating an Australian history programme in years 3-10.

The lunch break was brief, but long enough to produce several, intense caucusing groups. It was then Melleuish's turn to give his ten-minute talk. Oddly, considering the importance of the occasion, his presentation seemed confused and unfocused. During the discussion that followed, Indigenous representatives then asked of Melleuish, in a sharp way, where were the Aborigines? In turn, academic historians were quick to query the high levels of understanding required by students. The three school representatives then rejected the Melleuish framework on teachability grounds. The solitary curriculum official (Jenny Lawless from NSW) rejected it as well. The only Summiteer who was persistently vocal in support of the Melleuish approach was Mark Lopez, another relatively unknown participant who had published a book about multiculturalism from a strongly conservative standpoint. Henderson and Kelly made sporadic, general points but were clearly out of their depth with Henderson apparently distracted by some other task as the rest of us debated and argued.

By mid-afternoon, following a barrage of polite criticism, Melleuish's proposed course had been finished off, to his visible indignation. That was when John Hirst came up with an improvised "questions and milestones" approach. This concept was an attempt to frame Australian history as a set of large questions, within which a series of key events would be studied. Hirst's plan was gratefully accepted by almost all there, probably on the grounds that it seemed sensibly broad and there was no other option offered. The key event at the summit therefore was the rejection of the Melleuish approach and the insertion of an unscheduled, professionally devised plan. Interestingly, when Bob Carr, as the afternoon's chair, wound up the summit at 5 p.m., Melleuish, Lopez, Henderson and Kelly, the four Summiteers with strong neo-conservative links, went into what I can only describe as an urgent and agitated huddle.

\subsection{Re-inventing School History: Losing the Plot?}

Imagine my surprise when, on the Saturday following the summit (19th August), Chris Mitchell's Weekend Australian published a massive spread "Story of a True Blue Country" - a carefully written 2,800-word Melleuish piece, complete with impressive graphics of Captain Cook, Indigenous art, Gallipoli and the Whitlam dismissal. It was the sort of article that normally might take a week or more to solicit, write and edit. It was, however, merely an edited version of Melleuish's paper, as presented, and roundly discarded, on the previous Thursday. The Saturday article was published as if nothing unusual had happened at all on the Thursday prior. It was as if Melleuish's programme had not already been summarily dispensed with in favour of the Hirst extemporisation. The Saturday spread then raised in the minds of some sceptical observers the possibility that the summit had indeed 
been carefully staged and that the prime minister's office, The Australian, and some Summiteers, had been in on the act.

Remembering the lessons learned after Labour prime minister Bob Hawke's abortive tax summit in 1985, which ended in embarrassing disagreement, it is almost unthinkable that Howard, canny a politician as he was at that stage, would set up such a high-profile, 1-day conference unless he had all his arrangements neatly in a row. Was it the case therefore that tactics were planned in the prime minister's office, with the proposed Melleuish draft syllabus meant for rubberstamping on the Thursday, to be celebrated in triumphant style by The Australian on the following Saturday and tweaked by a government-friendly panel in the weeks thereafter?

Whatever the case, a question arises. Were the prime minister's summit organisers so very confident that they felt they did not need a fallback position? If so, the PM's office slipped up badly and it was a "whatever were they thinking?" moment, for, on the day when Plan "A" failed, there was no Plan "B." And that is how we were left with John Hirst's Questions (undesirably ambiguous from a neo-conservative point of view) and milestones (not enough facts). ${ }^{19}$ In summary, the summit was a combination of an ideologically motivated conspiracy and policy confusion.

\subsection{After the Summit}

Post-summit analysis in the media produced general puzzlement and some illtempered attacks on the questions (bad) and milestones (too few) by the more vocal conservative commentators. Melleuish's public response to the outcome of the summit included a sulky lament in The Australian that a (i.e. his) "great opportunity had been missed" (23rd August). Coincidentally, this article appeared on the same day that columnist Janet Albrechtsen, culture warrior and Howard-appointed ABC Board member, launched yet another neo-liberal personal attack on Stuart Macintyre, the supposedly seditious, omnipresent and omnipotent pinko. John Hirst, a stickler for courtesy and accuracy, publicly chided the disappointed grouches but that did not stop Windschuttle later (Quadrant, January 2007) joining in the debate, and, in a wonderful piece of irony, blaming the "failure" of the summit on an unnamed group of conspirators. His response to post-summit events was not too happy either:

The summit appointed a sub-committee to go off and rewrite the curriculum. The subcommittee has a majority of leftists, including an inevitable Aboriginal woman, Jackie Huggins, plus the president of the History Teachers' Association, Nick Ewbank, who, as I noted earlier, has since endorsed a curriculum unit about the SIEV-X sinking.

\footnotetext{
${ }^{19}$ It is the experience of the author that most conservative politicians have an unsophisticated view of history as a chronicle of unassailable facts. While this not a trait confined only to conservatives, it is predominant amongst conservative political parties in for example the UK and the USA. See for example, Graham (1993), Taylor (1995), Phillips (1998) and Nash et al. (1999).
} 
In short, the argument here is that, at the summit and on the day, Howard lost control of the process. One interpretation might be that in stacking the deck and insisting that Melleuish, an educationally inexperienced culture warrior, not an educator, be given the key job of designing a national programme, Howard had over-reached himself. When the summit went badly off track, and with no fallback plan immediately to hand, Howard was unable (at that time) to regain direction of a project that was so close to his heart and to his ideological convictions because he had promised that the summit outcome would be the solution to all his school history problems.

Post-summit criticism of Hirst's proposals (questions still bad, more facts good) were further inflamed by an astonishing claim by Julie Bishop, in her home state and speaking at the Fremantle HTAA conference (6 October 2006), that curriculum officials were Maoists. She was indeed all set to say exactly that, as it had appeared in her press release the day before the conference, which was that history curriculum comes "straight from Chairman Mao" through "ideologues experimenting with the education of young people from a comfortable position of unaccountability." My information was that DEST had not vetted the speech (almost certainly drafted by one of Bishop's advisers). Her department hit the roof, as did the HTAA organisers and history teachers, and Mao was left out of the actual speech delivery but the damage had been done. ${ }^{20}$ The "sensible centre" rhetoric had all but disappeared. Now it was time for Bishop to try to repair some of the damage.

\subsection{The School History Working Party}

After a post-summit hiatus, this time of two months, the summit-endorsed and selfselecting Working Party of six ${ }^{21}$ chaired by DEST Secretary Lisa Paul, spent a day in October further developing the questions and the milestones. In the end there were about 20 milestones and 13 or so questions. After a further pause of four months, it was then my job to take this consultation draft in Australian history (years 3-10) around the country as a prelude to agreement by the states and territories.

During this post Working Party consultation process (late 2006-early 2007) there was strong pressure indirectly coming from the PM's office for more "particularities" (i.e. detailed facts) and "biographies." I felt that these "particularities" were

\footnotetext{
${ }^{20}$ See, for example 'Education hijacked by left-wing, says Bishop', The West Australian 6th October 2006, 'Fast-talking Bishop shoots from the hip: education groups', The West Australian, 7th October 2006 and 'Little Red Curriculum' (editorial) The Australian, 14th October 2006.

${ }^{21}$ John Hirst, John Gascoyne (NSW historian); Jennifer Lawless (New South Wales Board of Studies); Jackie Huggins (Reconciliation Council); Nick Ewbank (HTAA), and the author. Melleuish, when asked by Bishop at the end of the summit proceedings if he would join, vigorously shook his head.
} 
just a demand for yet more facts, and that the biographical angle was a request for stories of the great and good. This was puzzling at the time but all was to become plain later on.

The early-2007 consultation process involved teachers, curriculum officials, academic historians and history educators from across Australia. All state and territory departments were consulted. The surprise here was that, on my journey, there was a remarkable lack of disagreement about the idea of Australian history as core. What concerned many, though, was that the draft was content-heavy and did not pay enough attention to local historical developments.

The final version of a 24-page document, Outline of a Model Curriculum Framework: Australian History Years 3-10, based on the Working Party draft and feedback during the consultation period was sent to DEST in April 2007 and it was approved. ${ }^{22}$ The document had a strong pedagogy section, based on historical literacy, a primary-level section which outlined four (either integrated or disciplinebased) topics which could move from local to regional to national topics, and a secondary-level section which had 10 broad topics-as-questions, 30 milestones (with detailed dot points suggesting Investigations) and a reduced number of questions as studies in depth. The pressure for biographies was expressed in my draft as biographical perspectives - on the basis that these give colour to history and reduce the tendency to over-generalise experience, which is a common fault at the school level.

Although I had reservations about the master narrative implications of milestones, that was my brief and the key thing in the April draft was that there were enough significant events (milestones) to give a sense of development but they were few enough in number for students to examine them in depth, contest their inclusion and, if necessary, argue for additional milestones. It was all a bit primitive, but my job was to work within a political brief and, at the same time, try to keep it professional. Then came another Howard bombshell.

\subsection{The School History Curriculum Reference Group: The Blainey Panel}

I was at a conference in Darwin in late June when I got an urgent phone call from DEST letting me know that there would be a hastily convened review panel and asking me if I would make a presentation to it about the April draft. The most senior member of the panel was to be the Geoffrey Blainey (still Howard's favourite historian), whom I had met several times and who had always been courteous and considerate in his dealings with me.

Notwithstanding Blainey's professional demeanour, I knew what was happening. My April consultation draft was to be re-shaped by the panel to make it more

\footnotetext{
${ }^{22}$ The document was never released.
} 
in line with the PM's views. However, I played a straight bat, deciding that it was better to stay inside the process than to be outside. Again, there followed a break in activity for three months and I was eventually invited to Canberra in early September to present to an attentive group comprising Geoffrey Blainey, Elizabeth Ward (former NSW private school principal), Gerard Henderson (a Howard admirer) and Nick Brown (highly regarded unaligned academic historian working on the Australian Dictionary of Biography). None of the panellists was a serving teacher.

What later became clear was that the panel, officially known as the Curriculum Reference Group but more commonly referred to as "The Blainey Panel," convened as a rescue squad, had been presented with my April draft document with a brief to cut it back, forget primary school history and add in "particularities" and biographies (hence Nick Brown's inclusion) - all in 1 day. At the same time, the redrafting process was underway in the PM's office, almost certainly under the direction of John Kunkel, the PM's chief speechwriter. ${ }^{23}$

The panel's job therefore was, in a single day in mid-September, to meet for the first time and review the April draft. Thereafter, the more active panel members communicated busily by email and by phone before they came up with a new draft, which went off to the PM's office where it was further vetted and modified. The final Howard-Kunkel document was then to be given, by implication as well as by explicit prime ministerial statement, the Blainey seal of approval. Realising that the Howard's political machinery would anyway easily roll over any professional objections, it was still worth attempting a public, pre-emptive move. Accordingly, I wrote a full-page article for The Age ("A roadmap for history's future," 10th September 2006) in which, amongst many other points, mainly about, political interference, I remarked that "if there is no informed teacher involvement in the planning process we'll end up with teacher disengagement, bad Australian history and poor student learning."

\subsection{The Prime Minister's Guide to the Teaching of Australian History in Schools}

Whatever the case, on 11 October, it was the prime minister, and not Julie Bishop the education minister, who launched a glossy Guide to the Teaching of Australian History in Years 9 and 10, a document that contained no less than 77 milestones, rather than the original 30. Interestingly, as far as the number of milestones is concerned, Howard's Guide tied in more or less with Carr's original 1998 NSW Years

\footnotetext{
${ }^{23}$ John Kunkel, economist, trade specialist and writer on trade with Japan, 1995 co-winner of the ANU's economics award, had almost certainly been running the "root and branch" history process in the PM's office since the Australia Day speech in 2006. His involvement might explain why the Australia-Japan trade agreement of 1957 popped up from nowhere in Howard's October 2007 Guide. Kunkel's key role in the proceedings was outlined to me by two confidential sources.
} 
9-10 syllabus which had a slightly fewer 60 topics for study. Furthermore, the questions/ investigations disappeared altogether and over 100 biographies were added, to "assist with the study." Primary-level history had disappeared altogether, as some of us suspected it might. We were straight back to the 1998 NSW version.

One telling feature of the new guide was that the prime minister's view of historical literacy was a very watered-down version of the original, with "moral judgement" dropped altogether and "contention and contestability" (historiography and public debate) rewritten as the more anodyne "explain and account for difference in historical interpretations." The whole thing was packed with detail and, although it had borrowed some of the April draft's pedagogy and perspectives, when push came to shove it was simply unteachable, if only because of the massive amount of content involved. I calculated it would take at least $350 \mathrm{~h}$ to teach, and the discursive elements were all but removed.

The overwhelming professional response was that the Howard document was part of a game of "political football" associated with his decline in popularity and the forthcoming general election. Queensland Premier Anna Bligh commented that the document would be seen as "another desperate, last minute effort by a prime minister who is in electoral trouble." ${ }^{24}$ All in all, I believe the Blainey panel was largely a well-intentioned but more tightly controlled mini-summit with, for Howard at least, a relaxed and comfortable outcome spoiled only by an election, which ironically produced another historical milestone, this time Howard failing to regain his NSW seat of Bennelong, the first sitting prime minister to do so since 1929.

\subsection{What Had Happened to Policy Reform in Australian History?}

I suggest that Howard knew he had lost control of the initiative back in August 2006. His plan, prior to the summit, had been to use the occasion to give an imprimatur to a NSW-style solution, to be written by a trusted neo-conservative academic historian. On the day, however, the plan fell apart and he was confronted by the post-summit wreckage that included Julie Bishop's impromptu convening of a (dangerously) self-selecting Working Party, without even the partial benefit of a bitter Melleuish's inclusion. Having already sold the summit's outcome as the end solution, Howard was unable to disown what had happened and to call off Julie Bishop's Working Party. He allowed the consultation process to take place, with his office monitoring and attempting to intervene in the drafting process. When the April 2007 draft was approved by DEST and by Bishop, Howard took it out of their hands, commissioned John Kunkel to workshop a ghost draft in his office, allowed

\footnotetext{
${ }^{24}$ See, for example, 'States mistrust the intent of Howard's history plan', The Age, 10th October 2006 and 'Howard's way fails school test' (Tony Taylor, feature article), The Age 14th January 2008.
} 
the panel to do their own rapid fire workshopping. This joint endeavour involving the Blainey panel gave the Guide unassailable credibility. What Howard and Kunkel did not tell the panel was that the PM's office would hijack the panel's recommended 77 optional milestones and turn them into compulsory topics, much to the fury of several panel members. ${ }^{25}$ The upshot was that, by October 2007, the original pre-summit scheme of Australian history years 3-10 had been all but reduced to the last 2 years of compulsory education. Years 9 and 10 were clearly the only sections of schooling with which the Howard government considered it worth bothering.

The timeline is important here. The Blainey panel met on 18 September. The Guide was launched, amidst the election campaign, on 11 October, a mere seventeen working days later. This was not solely the product of a group of four at a hectic one-day meeting (plus follow-up), but the joint product of two teams running in parallel. One team, the Blainey panel, was unaware of the other's existence. As in Conan Doyle's The Silver Blaze, when the significant point was that the dog did not bark in the night, Julie Bishop never denied that the matter had been taken out of her hands nor did John Howard ever deny that he had a major hand in the final product.

Interestingly, John Hirst published an article in a recent edition of the leftish Monthly. ${ }^{26}$ The gist of his article was that he had been asked to write an "official history" for the Immigration Department's new citizenship process. Contrary to the official line, he produced a theme-based, not a narrative-based official history which at first was blocked but later accepted after some serious to and fro with the Prime Minister's office. John Hirst's article details the close involvement of the PM's office in redrafting his version of events, a story that is consistent with postsummit behaviour. At the same time, even Geoffrey Blainey, history champion of the conservative side of politics, condemned supposed political interference in the awarding of the 2006 prime minister's $\$ 100000$ history prize. Blainey was chair of the prize selection panel (the panel also included Greg Melleiush) and the Blainey outburst undoubtedly implied that the interference, about how the prize was to be allocated, came from the prime minister's office. ${ }^{27}$ Attach Blainey's concerns about political interference in the awarding of the inaugural prime minister's history prize to Hirst's immigration exasperation and the interventionist summit process, and you can see a strong behavioural pattern emerging.

\footnotetext{
${ }^{25}$ Information based on confidential discussions after the panel was disbanded.

26 'Australia: the Official History', The Monthly February 2008.

${ }^{27}$ The two worthy final contenders were freelance history Peter Cochrane with his book Colonial Ambition, a highly regarded study of NSW colonial-era politics, and Les Carlyon's journalistic The Great War, which, interestingly, contained three footnoted references to the Howard family, with one footnote each to father and grandfather who served in the same battalion during that war. The Australian article 'Rudd to award Aussie writers' 5th December 2007, details the Blainey criticisms and the new Labor government's subsequent switch to a $\$ 100,000$ literary prize.
} 
In summary, what we witnessed in 2006-2007 was a period when, in a major case of high politics, five individuals - the former Prime Minister Howard, one of his senior advisers, Kunkel, a staffer in Julie Bishop's office, ${ }^{28}$ an obscure Wollongong historian, Melleuish and an editor at a major opinion-consolidating newspaper, Chris Mitchell ${ }^{29}$ - attempted, in different ways, to become the coercive owners, string-pullers and propagators of a crude, fact-based version of Australian history education. Of that group of five, none was an educator, all were men and none was Indigenous. This ambitious scheme, to impose a NSW model on years 9 and 10 was embarked upon notwithstanding the sincere efforts of most of the Summiteers, all of the members of the 2006 Working Party, all of the 2006-2007 consultees and the committed educators and professional historians of the Blainey panel, with a section of the latter very angry that they had been taken for a ride. ${ }^{30}$ Clearly, during the Howard era, school history was far too important to be left to teachers, to women, to Aboriginal representatives, or even to the historians.

\subsection{Conclusion}

In the new scheme of things, under a 2007 Rudd Labour government, national curriculum has again been taken up but, learning from the lessons of the past, this time initially under the management of a National Curriculum Board (NCB). The NCB (from 2009, known as the Australian Curriculum, Assessment and Reporting Authority or ACARA) works safely at arm's length from federal government interference, sensibly introducing reform in all major study areas and firmly involving states, territories, teachers, parents and other interested parties in the planning process. In the new regime, history has become one of four core areas, along with English, mathematics and science, and the design of the new history curriculum is firmly in the hands of historians, teachers and history educators, not within the grasp of politicians, staffers and crusading journalists.

\section{References}

Macintyre, S. \& Clark, A. (2003). The history wars. Melbourne: Melbourne University Press. Melleuish, G. (2006). The teaching of Australian history in Australian schools: a normative view. Canberra: The Department of Education Science and Training.

\footnotetext{
${ }^{28}$ Who remains anonymous.

${ }^{29}$ Almost certainly with the assistance of his 2001-2008 opinion editor Tom Switzer, see Taylor (2008) pp. 284-285.

${ }^{30}$ Confidential correspondence with the author.
} 
Nash, G. B., Crabtree, C., \& Dunn, R. E. (1999). History on trial: culture wars and the teaching of the past. New York: Alfred Knopf.

Phillips, R. (1998). Nationhood and the state: a study in educational politics. London: Cassell.

Taylor, T. (1995). Movers and shakers: high politics and the origins of the national curriculum. The Curriculum Journal, 6(2), 161-184.

Taylor, T. (2004). Disputed territory: the politics of historical consciousness in Australia. In P. Seixas (Ed.), Theorizing historical consciousness (pp. 217-239). Toronto: University of Toronto Press.

Taylor, T. (2008). Denial: history betrayed. Melbourne: Melbourne University Press. 


\title{
Chapter 3 \\ Teachers, History Wars and Teaching History Grade 6 in Greece
}

\author{
Stilianos Meselidis
}

\subsection{History Wars in Greece: Introduction}

It seems surreal now that such a small book, of only 136 pages, between 2006 and 2007, could have contributed towards inter-party strife within the ruling Greek government; its reduced majority at the election of 16 September, 2007; the failure by the Minister of Education, Marietta Giannakou, and her deputy minister George Kalos, to be re-elected to parliament; the hostility of the Church of Greece; the rise of the ultra-right-wing nationalist party of L.A.O.S., which won, for the first time, 10 seats in Greece's 300-member chamber of parliament; enormous media spotlight and the chagrin of many teachers who systematically refused to teach the contents of the book, not to mention the opposition of many ordinary people. The book, in question, was the 2006-2007 school history textbook for year 6 primary school which was written under the supervision of Maria Repousi from the University of Thessaloniki.

It was introduced as the new main school history textbook, for that level, in all government primary schools, in September 2006. Its contents primarily included an examination of the history of Greece from the 1400s until approximately 1981. It addressed the rule of the Ottoman Empire over Greece, the Greek war of Independence (1821-1827) against the Ottoman Empire and the history of the new Greek state post 1827 until the present, with special concluding emphasis on Greece's admission to the European Economic Community (1981).

The purpose of this study is to investigate, through an analysis of the controversies surrounding that textbook, the new ideological and methodological developments in teaching history in primary schools, between 2006 and 2007, in Greece. As a harbinger of new ideologies which challenged the traditional narrative of modern Greek history since the 1970s in school history textbooks, the 2006-2007 year 6 school history textbook became the symbol of innovation, for many, in values and methodology. This is because it sought to ideologically re-position a new

S. Meselidis $(\triangle)$

Faculty of Education, Australian Catholic University Limited, St Patrick's Campus,

115 Victoria Parade, Fitzroy, VIC 3065, Australia 